\title{
Intrathecal Antibody Production Against Epstein-Barr, Herpes Simplex, and Other Neurotropic Viruses in Autoimmune Encephalitis
}

\author{
Philipp Schwenkenbecher, MD, Thomas Skripuletz, MD, Peter Lange, Marc Dürr, MD, Felix F. Konen, MD, \\ Nora Möhn, MD, Marius Ringelstein, MD, Til Menge, MD, Manuel A. Friese, MD, Nico Melzer, MD, \\ Michael P. Malter, MD, Martin Häusler, MD, Franziska S. Thaler, MD, Martin Stangel, MD, Jan Lewerenz, MD, \\ and Kurt-Wolfram Sühs, MD, on behalf of the German Network for Research on Autoimmune Encephalitis
}

Neurol Neuroimmunol Neuroinflamm 2021;8:e1062. doi:10.1212/NXI.0000000000001062

\author{
Correspondence \\ Dr. Schwenkenbecher \\ schwenkenbecher.philipp@ \\ mh-hannover.de
}

\begin{abstract}
\section{Background and Objectives}

Neurotropic viruses are suspected to play a role in the pathogenesis of autoimmune diseases of the CNS such as the association between the Epstein-Barr virus (EBV) and multiple sclerosis (MS). A group of autoimmune encephalitis (AE) is linked to antibodies against neuronal cell surface proteins. Because CNS infection with the herpes simplex virus can trigger anti-NMDA receptor (NMDAR) encephalitis, a similar mechanism for EBV and other neurotropic viruses could be postulated. To investigate for previous viral infections of the CNS, intrathecally produced virus-specific antibody synthesis was determined in patients with $\mathrm{AE}$.
\end{abstract}

\section{Methods}

Antibody-specific indices (AIs) against EBV and measles, rubella, varicella zoster, herpes simplex virus, and cytomegalovirus were determined in 27 patients having AE (anti-NMDAR encephalitis, $n=21$, and LGI1 encephalitis, $n=6$ ) and in 2 control groups comprising of 30 patients with MS and 21 patients with noninflammatory CNS diseases (NIND), which were sex and age matched.

\section{Results}

An intrathecal synthesis of antibodies against EBV was found in 5/27 (19\%) patients with AE and 2/30 (7\%) of the patients with MS. All these patients had also at least 1 additional elevated virus-specific AI. In contrast, in none of the patients with NIND, an elevated virus-specific AI was detected.

\section{Discussion}

Intrathecally produced antibodies against EBV can be found in patients with AE and MS but only together with antibodies against different neurotropic viruses. Evidence of these antibodies is the result of a polyspecific immune response similar yet distinct from MS response rather than an elapsed infection of the CNS.

\footnotetext{
From the Department of Neurology (P.S., T.S., F.F.K., Nora Möhn, M.S., K.-W.S.), Hannover Medical School; Department of Neurology (P.L.), Georg August University Göttingen; Department of Neurology (M.D., J.L.), Ulm University; Department of Neurology (M.R.), Medical Faculty, Heinrich-Heine-University Düsseldorf; Department of Neurology (M.R., T.M.), Centre for Neurology and Neuropsychiatry, LVR-Klinikum, Heinrich-Heine-University Düsseldorf; Institute of Neuroimmunology and Multiple Sclerosis (M.A.F.), University Medical Center Hamburg-Eppendorf; Department of Neurology with Institute of Translational Neurology (Nico Melzer), University Hospital Muenster; Department of Neurology (M.P.M.), University Hospital Cologne; Division of Neuropediatrics and Social Pediatrics (M.H.), Department of Pediatrics, Medical Faculty, RWTH Aachen University; and Institute of Clinical Neuroimmunology (F.S.T.), University Hospital and Biomedical Center, Ludwig-Maximilians University Munich, Germany.

Go to Neurology.org/NN for full disclosures. Funding information is provided at the end of the article.
}

German Network for Research on Autoimmune Encephalitis (GENERATE) coinvestigators are listed in Appendix 2 at links.Iww.com/NXI/A541.

The Article Processing Charge was funded by Hannover Medical School.

This is an open access article distributed under the terms of the Creative Commons Attribution-NonCommercial-NoDerivatives License 4.0 (CC BY-NC-ND), which permits downloading and sharing the work provided it is properly cited. The work cannot be changed in any way or used commercially without permission from the journal. 


\section{Glossary}

$\mathbf{A E}=$ autoimmune encephalitis; $\mathbf{A I}=$ antibody-specific index; $\mathbf{C M V}=$ cytomegalovirus; EBNA-1 = EBV-encoded nuclear antigen-I; EBV = Epstein-Barr virus; EBV-VCA = EBV-virus capsid antigen; HSV = herpes simplex virus; LGI1 = leucine-rich, glioma-inactivated 1; $\mathbf{m R S}$ = modified Rankin Scale; MRZ = measles, rubella, varicella zoster; $\mathbf{M S}=$ multiple sclerosis; NIND = noninflammatory neurologic disease; NMDAR = NMDA receptor; NPH = normal pressure hydrocephalus; IIH = idiopathic intracranial hypertension; $\mathbf{O C B}=$ oligoclonal band; $\mathbf{Q A l b}=\mathrm{CSF} /$ serum albumin ratio; $\mathbf{V Z V}=$ varicella zoster virus.

Autoimmune encephalitis $(\mathrm{AE})$ is a group of inflammatory CNS diseases associated with antibodies against neural antigens. ${ }^{1}$ These antibodies can either be directed against intracellular antigens or against cell surface antigens causing neuronal dysfunction. ${ }^{2}$ The most common $\mathrm{AE}$ is associated with antibodies against the cell surface antigen NMDA receptor (NMDAR). ${ }^{1}$ The second most common one is associated with antibodies against leucine-rich, glioma-inactivated 1 (LGI1). ${ }^{1}$ A clinical association between herpes simplex virus (HSV) encephalitis and antiNMDAR encephalitis has been described. ${ }^{3}$ It is hypothesized that the HSV, and possibly other neurotropic viruses, can trigger the production of antibodies against the NMDAR and other neuronal cell surface proteins. ${ }^{1}$ One mechanism could be that these viruses may lyse neurons, releasing antigens that sensitize antibodies to the NMDAR and initiate autoimmune reactivity. ${ }^{4}$ Epstein-Barr virus (EBV), another member of the herpes virus family, might act in a similar way as it is known to be a potential trigger for a wide range of autoimmune disorders. ${ }^{5}$

An association between multiple sclerosis (MS) and EBV infections has been described in several articles. ${ }^{6}$ In particular, the almost universal EBV seroprevalence in patients with MS and the extremely low MS risk in EBVseronegative patients have been emphasized..$^{7-9}$ Of interest, the frequency of intrathecally produced antibodies to EBV in patients with MS is paradoxically low compared with that of other common viruses. ${ }^{6}$ In comparison with MS, little is known about the association between EBV and $\mathrm{AE}$.

In this study, we investigated the frequency and titer of intrathecal synthesis of antibodies against EBV and HSV, and other neurotropic viruses measles, rubella, varicella zoster (MRZ), and cytomegalovirus (CMV), in patients with $\mathrm{AE}$ in comparison to control groups consisting of patients with MS and noninflammatory neurologic diseases (NIND).

\section{Methods}

\section{Patients}

Medical records of patients admitted to the Department of Neurology at Hannover Medical School between 2014 and 2019 were screened for the diagnosis of $\mathrm{AE}$ with detection of NMDAR or LG1 antibodies. In addition, patients who were recruited by the German Network for Research on Autoimmune Encephalitis (GENERATE; generate.net) with detection of anti-NMDAR or anti-LGI1 antibodies enrolled until 2016 were identified, and clinical and laboratory data were extracted from the GENERATE database. Only adult patients aged 18 years or older who fulfilled the recently suggested diagnostic criteria for definitive $\mathrm{AE}$ (with detection of antibodies against cell surface). ${ }^{10}$ with a sufficient clinical documentation and a complete CSF workup without evidence of any other inflammatory disease of the CNS were included. Part of the results of 20 of these (14 patients with anti-NMDAR encephalitis and 6 with anti-LGI1 encephalitis) including the AIs for measles, rubella, and varicella zoster virus (VZV) is described in more detail in the accompanying article (Dürr et al., 2021, submitted).

The modified Rankin Scale (mRS) score, which indicates the extent of functional impairment due to the neurologic disease, was extracted from the medical records for all patients with AE. The peak $\mathrm{mRS}$ score during the hospital stay and the mRS score at discharge were evaluated.

The control group of NIND consisted of patients with normal pressure hydrocephalus (NPH) and patients with idiopathic intracranial hypertension (IIH). Prodromal symptoms included fever and signs of upper respiratory or gastrointestinal infection, which occurred within 4 weeks before onset of neurologic symptoms.

Another control group comprised patients with MS diagnosed according to the McDonald criteria of 2010. Patients in the control groups were admitted to Hannover Medical School between 2016 and 2018 and sex and age matched.

\section{Analytical Procedures}

CSF and paired serum samples were collected as part of routine diagnostic workup. A leukocyte count in CSF samples $>4$ cells $/ \mu \mathrm{L}$ was defined as pleocytosis. The cutoff for total CSF protein levels was set to $>500 \mathrm{mg} / \mathrm{L}$. Concentrations of albumin, IgG, IgA, and IgM were measured nephelometrically, and the CSF/serum ratios of albumin, IgG, IgA, and IgM were calculated. The age-dependent upper reference limit for the CSF/serum ratio of albumin (QAlb), as an indicator for the CSF/blood barrier, was calculated according to the formula $Q_{\text {Albumin }}=4+\left(\right.$ age in y/15) ${ }^{11}$ The intrathecally produced fraction of IgG, IgA, and IgM was determined by plotting the CSF/serum ratio vs $\mathrm{Q}_{\mathrm{Alb}}$ according to the 
Table 1 CSF Characteristics of Patients With AE (Anti-NMDAR and LGI1) in Comparison to Control Groups (MS and NIND)

\begin{tabular}{|c|c|c|c|c|c|c|}
\hline & \multicolumn{3}{|l|}{$\mathrm{AE}$} & \multicolumn{2}{|l|}{ Controls } & \multirow[b]{2}{*}{$p$ Value } \\
\hline & Total $(n=27)$ & Anti-NMDAR $(n=21)$ & LGI1 $(n=6)$ & MS $(n=30)$ & NIND $(n=22)$ & \\
\hline Sex: female/male (n) & $20 / 7$ & $17 / 4$ & $3 / 3$ & $21 / 9$ & $17 / 5$ & 0.8382 \\
\hline Age: median, range (y) & $34(18-72)$ & $26(18-68)$ & $52.5(40-72)$ & $32(17-70)$ & $34(22-65)$ & $<0.0001^{\mathrm{a}}$ \\
\hline Infectious prodromi: (n) & $5 / 23(22 \%)$ & $5 / 17(29 \%)$ & 0 & - & - & - \\
\hline \multicolumn{7}{|l|}{ CSF findings } \\
\hline Cell count: median, range $(\mu / L)$ & $3(0-226)$ & $6(1-226)$ & $1(0-11)$ & $5.5(1-44)$ & $1(0-3)$ & $<0.0001^{\mathrm{a}}$ \\
\hline CSF protein: median, range (mg/L) & $377(163-1,310)$ & $377(163-1,310)$ & $385(210-1,000)$ & $407(215-719)$ & $344(198-827)$ & 0.2039 \\
\hline Albumin quotient, median, range & $4.8(3-18)$ & $4.5(3-18)$ & $6.3(3.1-13)$ & $4.9(2.6-12.1)$ & $4.4(1.5-12.9)$ & 0.506 \\
\hline Blood-CSF barrier dysfunction ( $n$ ) & $4 / 27(15 \%)$ & $2 / 21(10 \%)$ & $2 / 6(33 \%)$ & $7 / 30(23 \%)$ & $4 / 22(18 \%)$ & 0.7106 \\
\hline Intrathecal IgG (n) & $11 / 27(41 \%)$ & $11 / 21(52 \%)$ & 0 & $14 / 30(47 \%)$ & $1 / 22(5 \%)$ & $0.0035^{\mathrm{a}}$ \\
\hline Intrathecal IgA (n) & $4 / 27(15 \%)$ & $4 / 21(19 \%)$ & 0 & $1 / 30(3 \%)$ & 0 & 0.0735 \\
\hline Intrathecal IgM (n) & $8 / 27(30 \%)$ & $8 / 21(38 \%)$ & 0 & $10 / 30(33 \%)$ & 0 & $0.0105^{a}$ \\
\hline Oligoclonal bands ( $n$ ) & $17 / 27(63 \%)$ & $15 / 21(71 \%)$ & $2 / 6(33 \%)$ & 28/30 (93\%) & $2 / 22(9 \%)$ & $<0.0001^{\mathrm{a}}$ \\
\hline
\end{tabular}

Abbreviations: $\mathrm{AE}=$ autoimmune encephalitis; $\mathrm{LGI1}=$ leucine-rich, glioma-inactivated $1 ; \mathrm{MS}=$ multiple sclerosis; NMDAR = NMDA receptor; NIND = noninflammatory neurologic disease.

a Age: $p<0.0001$ AE vs NIND; $p<0.0001$ MS vs NIN. Cell count: $p<0.0001$ AE vs NIND; $p<0.0001$ MS vs NIND. Intrathecal IgG: $p=0.006$ AE vs NIND; $p=0.0014$ MS vs NIND. Intrathecal IgM: $p=0.0056$ AE vs NIND; $p=0.0029$ MS vs NIND. Oligoclonal bands: $p=0.0001$ AE vs NIND; $p<0.0001$ MS vs NIND; $p=0.008$ AE vs MS.

nomogram of Reiber (Reibergram). ${ }^{12} \mathrm{CSF}$ and serum samples were investigated for oligoclonal bands (OCBs) by isoelectric focusing with consecutive silver staining or immunoblotting. The intrathecally produced fraction of pathogen-specific antibodies $\left(\mathrm{Q}_{\text {spec }}\right)$ was determined by calculating the pathogen-specific CSF/serum antibody index (AI) according to the formula: $\mathrm{Q}_{\mathrm{spec}} / \mathrm{Q}_{\mathrm{gG}}$. In case of an intrathecal IgG production as indicated by the Reibergram $\left(\mathrm{Q}_{\mathrm{IgG}}>\mathrm{Q}_{\mathrm{lim}}\right)$, the $\mathrm{AI}$ was calculated as $\mathrm{Q}_{\mathrm{spec}} / \mathrm{Q}_{\lim }$ to Reiber and Lange. ${ }^{12,13}$ The cutoff for a positive AI was set to values $\geq 1.5 .^{12,13}$ Titer of pathogen-specific IgG in serum and CSF was determined by ELISA from Virion/Serion (Würzburg, Germany) for IgG against EBV-encoded nuclear antigen1 (EBNA-1), EBV-virus capsid antigen (EBV-VCA), and IgG against measles, rubella, VZV, HSV, and CMV. The detection antibody from the ELISA kit was exchanged for a polyclonal rabbit anti-human IgG-HRP from Agilent (Santa Clara, United States) to improve sensitivity.

To calculate arbitrary units, a standard curve derived of a positive standard serum pool was applied. The highest standard concentration defined as 100 arbitrary units was adjusted to an optical density of approximately 2.0. CSF and serum samples were then investigated with reference to the standard curve. Standard predilutions of 1:25 and 1:100 for CSF and 1: 5,000 and 1:20,000 for serum were chosen to fit the linear range of the standard curve. The absorbance values were then referred to the standard curve to obtain arbitrary concentration unit. ${ }^{12}$ If at least 2 of the antibody indices against measles, rubella, and VZV are elevated, a polyspecific immune response, also called MRZ reaction, can be stated as positive.

\section{Statistical Analysis}

GraphPad Prism version 5.02 was used for statistical analysis. The level of statistical significance was set to $p<0.05$. Data are described by medians and range (min-max). The D'AgostinoPearson omnibus normality test was used to assess for normal distribution of values. The Kruskal-Wallis test with Dunn multiple comparison post hoc test was applied for group comparison and Mann-Whitney $U$ test for comparison of 2 groups. The Wilcoxon rank test was used for paired sample analysis and $\chi^{2}$ and Fisher exact tests for categorical data assessment. The Grubbs test was performed to identify significant outlier.

\section{Standard Protocol Approvals, Registrations, and Patient Consents}

This study was approved by the Ethics Committee of the Hannover Medical School (2481-2014).

\section{Data Availability}

Anonymized data not published within this article will be made available by request from any qualified investigator.

\section{Results}

A total of 27 patients with $\mathrm{AE}$ were included in this study, of which 21 patients had anti-NMDAR encephalitis and 6 
Table 2 Intrathecal Immunoglobulin Synthesis Against Neurotropic Viruses in Patients With AE (anti-NMDAR and LGI1) in Comparison to Control Groups (MS and NIND)

\begin{tabular}{|c|c|c|c|c|c|c|}
\hline \multirow[b]{3}{*}{ Virus antigen } & \multicolumn{5}{|c|}{ Intrathecal immunoglobulin synthesis } & \multirow[b]{3}{*}{$p$ Value } \\
\hline & \multicolumn{3}{|l|}{$\mathrm{AE}$} & \multicolumn{2}{|l|}{ Controls } & \\
\hline & Total $(n=27)$ & Anti-NMDAR $(n=21)$ & LGI1 $(n=6)$ & MS $(n=30)$ & NIND ( $n=22)$ & \\
\hline EBNA-I & $2 / 27(7 \%)$ & $2 / 21(10 \%)$ & 0 & $2 / 30(7 \%)$ & 0 & 0.4399 \\
\hline EBV-VCA & $4 / 27(15 \%)$ & $3 / 21(14 \%)$ & $1 / 6(17 \%)$ & $1 / 30(3 \%)$ & 0 & 0.0735 \\
\hline Measles & $4 / 27(15 \%)$ & $4 / 21(19 \%)$ & 0 & $8 / 30(27 \%)$ & 0 & $0.03^{a}$ \\
\hline Rubella & $4 / 27(15 \%)$ & $4 / 21(19 \%)$ & $1 / 6(17 \%)$ & $9 / 30(30 \%)$ & 0 & $0.0151^{a}$ \\
\hline Varicella zoster & $7 / 27(26 \%)$ & $7 / 21(33 \%)$ & 0 & $10 / 30(33 \%)$ & 0 & $0.0121^{a}$ \\
\hline Herpes simplex & $7 / 27(26 \%)$ & $7 / 21(33 \%)$ & $1 / 6(17 \%)$ & $4 / 30(13 \%)$ & $1 / 22(5 \%)$ & 0.1091 \\
\hline CMV & $6 / 27(22 \%)$ & $5 / 21(24 \%)$ & $1 / 6(17 \%)$ & $1 / 30(3 \%)$ & 0 & $0.0098^{a}$ \\
\hline
\end{tabular}

Abbreviations: $\mathrm{AE}$ = autoimmune encephalitis; $\mathrm{CMV}=$ cytomegalovirus; EBNA-1 = EBV-encoded nuclear antigen-l; EBV = Epstein-Barr virus; $\mathrm{LGI1}=$ leucine-rich, glioma-inactivated 1; MS = multiple sclerosis; NMDAR = NMDA receptor; NIND = noninflammatory neurologic disease; VCA = virus capsid antigen.

${ }^{a}$ Measles: $p=0.0150$ MS vs NIND. Rubella: $p=0.0066$ MS vs NIND. Varicella zoster: $p=0.0123$ AE vs NIND; $p=0.029$ MS vs NIND. CMV: $p=0.00265$ AE vs NIND; $p$ $=0.0446 \mathrm{MS}$ vs NIND.

patients had LGI1 encephalitis. The MS cohort consisted of 30 patients, 26 patients with relapsing-remitting MS, 2 patients with primary progressive MS, and 2 patients with secondary progressive MS. The NIND control cohort consisted of 20 patients with IIH and 2 patients with NPH.

More women were in the group of patients with anti-NMDAR encephalitis ( 17 women/4 men), and the sex ratio was balanced in the group of patients with anti-LG1 encephalitis (3 women $/ 3$ men). In the groups of patients with MS and NIND that were age and sex matched, more women than men were included with a similar ratio like in the group AE.

\section{CSF Parameters}

Routine CSF findings of patients with $\mathrm{AE}$ and patients of the control groups are summarized in Table 1.

A CSF pleocytosis was found in $13 / 27$ patients with $\mathrm{AE}$ (45\%), mostly anti-NMDAR (anti-NMDAR encephalitis 12/ 21 and LGI1 encephalitis 1/6), in 19/30 patients (63\%) with MS but in none of the patients with NIND. The CSF leukocyte count was higher in patients with $\mathrm{AE}$ and patients with MS than in patients with NIND $(p<0.0001)$. The total CSF protein concentration was above $500 \mathrm{mg} / \mathrm{L}$ in 7 patients with AE (26\%), 7 patients with MS (23\%), and 4 patients with NIND (18\%). A CSF-blood barrier dysfunction, indicated by an albumin quotient elevation, could be detected in 4 patients with $\mathrm{AE}$ (15\%), 7 patients with MS (23\%), and 4 patients with NIND (18\%). An intrathecal IgG synthesis was more often detected with Reiber diagram in patients with $\mathrm{AE}$ ( $p=$ $0.00060)$ and patients with MS $(p=0.0014)$ than in patients with NIND. Likewise, IgM synthesis was more common in patients with $\operatorname{AE}(p=0.0056)$ and patients with MS ( $p=$ $0.0029)$ than in patients with NIND.
In 17 patients with $\mathrm{AE}$ (63\%), OCBs restricted to CSF were identified (15 patients with anti-NMDAR encephalitis and 2 patients with LGI1 encephalitis). OCBs restricted to CSF were also identified in 28 patients with MS (93\%) and 2 patients with NIND (9\%). OCBs were more frequently found in patients with MS $(p<0.0001)$ and patients with $\mathrm{AE}(p<$ $0.0001)$ than in patients with NIND. In patients with MS OCBs were more frequently found than patients with $\mathrm{AE}(p=$ 0.0080).

\section{Intrathecal Synthesis of EBV- and HSV- Specific Antibodies}

An intrathecal synthesis against at least $1 \mathrm{EBV}$ antigen was found in 5 patients with $\mathrm{AE}$ (19\%), 4 patients with antiNMDAR encephalitis, and 1 patient with LGI1 encephalitis. In 2 patients with anti-NMDAR encephalitis, intrathecal synthesis against EBV-VCA without a synthesis against EBVEBNA-1 was found. In 1 patient with anti-NMDAR encephalitis and 1 patient with LGI1 encephalitis, synthesis against EBV-EBNA-1 without a synthesis against EBV-VCA was detected. A combined synthesis against EBV-VCA and EBVEBNA-1 was detected in 1 patient with anti-NMDAR encephalitis. In 2 of the 5 patients with an elevated AI against EBV, a positive MRZ reaction was additionally found. The median AI was 2.4 (2.1-2.7) for EBV-VCA, and the 2 AIs for EBNA-1 were 2.0 and 2.6.

In the group of patients with MS, an intrathecal synthesis against EBV was found in 2 patients (7\%), 1 patient had an intrathecal synthesis against EBV-EBNA-1 (2.0) and another patient had a combination of synthesis against EBV-EBNA-1 (2.6) and EBV-VCA (2.1). In 1 of these patients, the MRZ reaction was positive. An isolated intrathecal synthesis against EBV was not found in any of the patients with AE or MS. 


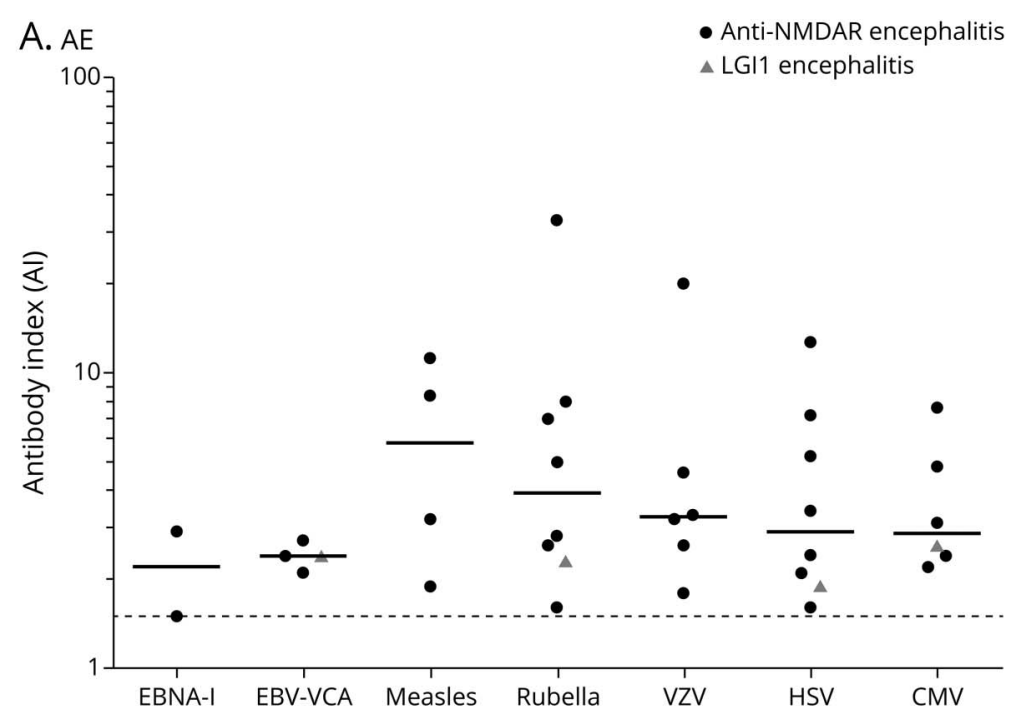

B. MS

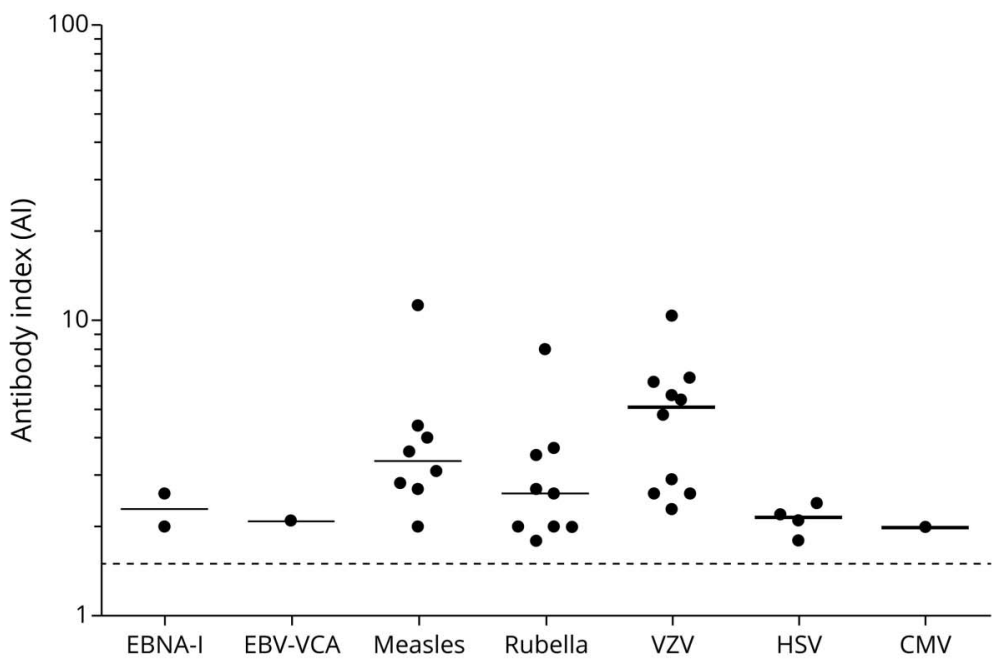

C. Frequency of multiple elevated Al

Two or more Al $\square$ Only one Al $\square \mathrm{NoAl}$

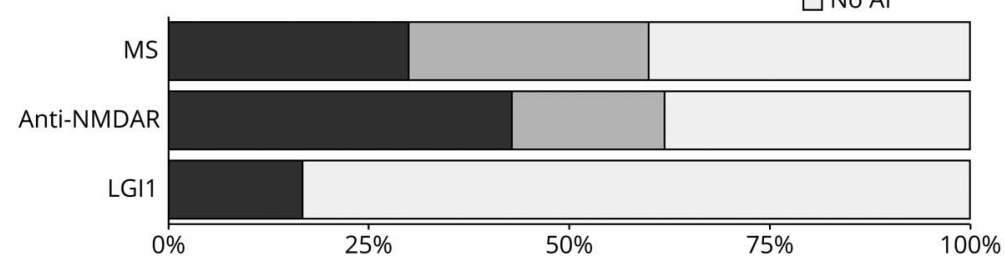

Distribution of antibody-specific virus indices (AI) against measles, rubella, VZV, HSV, or EBV (EBNA-1 and EBV-VCA) in $A E(A)$ and MS (B). Horizontal bars mark median Al values. Only Als $\geq 1.5$ were depicted. Frequency of multiple elevated Als against measles, rubella, VZV, HSV, or EBV in patients with $\mathrm{AE}$ and $\mathrm{MS}(\mathrm{C}) . \mathrm{AE}=$ autoimmune encephalitis; $\mathrm{Al}$ = antibodyspecific index; $E B V=$ Epstein-Barr virus; $H S V=$ herpes simplex virus; $\mathrm{MS}=$ multiple sclerosis; VZV = varicella zoster virus.

The HSV-AI was positive in 8 patients with $\mathrm{AE}$ (30\%, 7 patients with anti-NMDAR encephalitis and 1 patient with LGI1 encephalitis). The median HSV-AI was 2.4 (1.6-12-7). A positive MRZ reaction was found in only 2 of these patients (both had anti-NMDAR encephalitis). Of the patients with MS, 4 patients (13\%) had an elevated AI against HSV, and 2 of them also exhibited a positive MRZ reaction. Evidence of an intrathecal synthesis against EBV or HSV was not found in any of the patients with NIND.

\section{Intrathecal Synthesis of Other Virus- Specific Antibodies}

Details of intrathecal synthesis against neurotropic viruses are shown in Table 2 and Figure 1. An intrathecal synthesis of pathogen-specific antibodies against at least 1 neurotropic virus (measles, rubella, VZV, HSV, or CMV) was detected in 14 patients with $\mathrm{AE}$ (52\%) and 19 patients with MS (63\%) and was not found in the cohort of NIND. 


\section{A. Positive MRZ reaction}

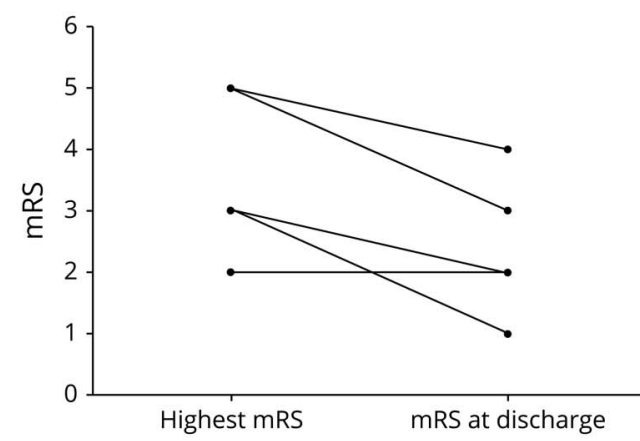

C. Intrathecal antibody synthesis against one neurotropic virus

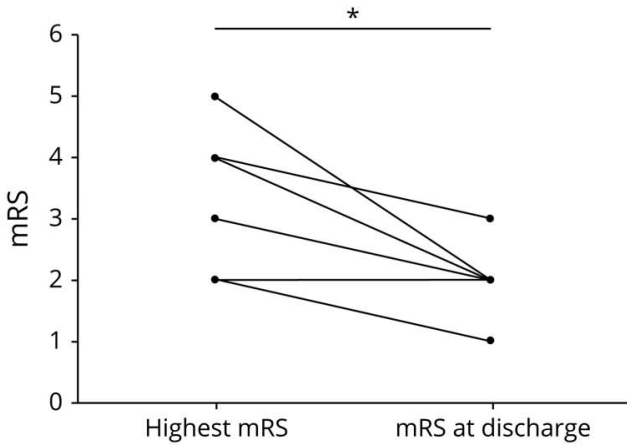

B. Intrathecal synthesis of EBV-specific antibodies

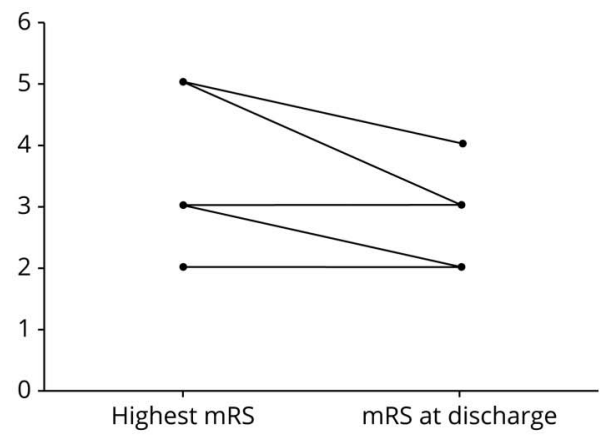

D. No intrathecal antibody synthesis against a neurotropic virus

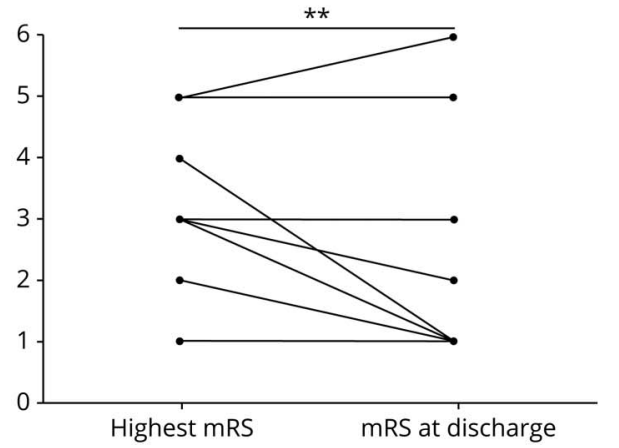

Highest documented mRS score during hospital stay and at discharge for patients with AE and positive MRZ reaction (A), an elevated Al against EBV (B), only 1 elevated Al against a neurotropic virus (C), and without evidence of an intrathecal antibody synthesis against a neurotropic virus (D). ${ }^{*} p=0.0310 ;{ }^{*} p=0.0092$. Al $=$ antibody-specific index; EBV = EpsteinBarr virus; $\mathrm{mRS}=$ modified Rankin Scale; MRZ = measles, rubella, varicella zoster.
In $\mathrm{AI}$-positive patients with $\mathrm{AE}$, the highest median $\mathrm{AI}$ was detected against measles $(5.8 ; 1.9-11.2)$, followed by rubella (3.9; 1.6-32.8), VZV (3.3; 1.8-20.0), HSV (2.9; 1.6-12.7), and CMV $(2.9 ; 2.2-7.6)$. A high AI was measured in 1 patient for measles (11.2), 1 patient for rubella (32.8), and 1 patient for VZV (20.0). In patients with MS, the highest median antibody indices were found against VZV (5.1; 2.3-10.4), followed by measles $(3.4 ; 2.0-11.3)$, rubella $(2.6 ; 1.8-8.0)$, HSV (2.2; 1.8-2.4), and CMV (2.0).A high AI was found in 1 patient for measles (11.3), 1 patient for rubella (8.0), and 1 patient for VZV (10.4). Elevated AIs against measles, rubella, and VZV were more often found in patients with MS than in patients with NIND (measles: $p=0.0150$; rubella: $p=0.0066$; $\mathrm{VZV}: p=0.029)$. In patients with AE, positive AI against VZV were more often detected than in patients with NIND ( $p=$ 0.0123 ) and elevated AI against CMV were more often found than in patients with MS $(p=0.0446)$ and NIND $(p=$ $0.0265)$.

In 5 patients with $\mathrm{AE}$ (19\%), the MRZ reaction was positive. All these patients had anti-NMDAR encephalitis. Elevated AIs against all 3 viruses were detected in only 1 patient. The MRZ reaction was positive in 7 patients with MS (23\%), of which 4 patients showed elevated AIs against 2 of the viruses and 3 patients had elevated AIs against all 3 viruses. In none of the patients with NIND, an MRZ reaction could be detected.
Of note, 2 MRZ-positive patients with anti-NMDAR encephalitis and 2 MRZ-positive patients with MS had an elevated $\mathrm{AI}$ against at least 1 other neurotropic virus (HSV, $\mathrm{CMV}$, and $\mathrm{EBV})$. In addition, 2 or more positive $\mathrm{AI}$ against $\mathrm{EBV}$, measles, rubella, VZV, HSV or CMV was found in 9 patients with anti-NMDAR encephalitis and 9 patients with MS.

\section{Indices of Acute or Prodromal Viral Infection}

In only 1 patient, an earlier CNS infection was documented in medical records. This patient had HSV encephalitis 3 months before diagnosis of anti-NMDAR encephalitis. The HSV-AI was not elevated in this patient. Prodromal symptoms were present in 5 patients with anti-NMDAR encephalitis weeks before onset of neurologic symptoms. In only 1 of these 5 patients, elevated AIs against EBV-VCA (2.7), HSV (3.4), and CMV (7.6) were detected. PCR test to detect viruses EBV, HSV, CMV, VZV, measles, and rubella in CSF were performed in 16/27 patients with $\mathrm{AE}$ (59\%): $\mathrm{EBV}$ in 10/27 patients (37\%, of which 2 patients had elevated EBV-AI), VZV in $15 / 27$ patients ( $56 \%$, of which 5 patients had elevated VZV-AI), HSV in $15 / 27$ patients (56\%; of which 4 patients had elevated HSV-AI), and CMV in $10 / 27$ patients (37\%, of which 3 patients had elevated CMV-AI). PCR test to detect measles or rubella were not performed. EBV, measles, rubella, VZV, HSV or CMV antigens were not found in CSF. 


\section{Disease Course of Patients With AE With Regard to Al Status}

The relationship between disease course and the MRZ status was investigated, in analogy to studies in which the polyspecific immune reaction was supposed to be of prognostic value for patients with MS. ${ }^{14}$

Figure 2 depicts the course of the mRS score during hospital stay and at discharge with regard to the detected AI for neurotropic viruses. No difference was found between neurologic impairment at disease peak (highest mRS score) in patients with a positive $\mathrm{MRZ}$ reaction, an elevated AI against only 1 neurotropic virus, an elevated $\mathrm{AI}$ against $\mathrm{EBV}$, and no elevated AI against a neurotropic virus. There was also no difference among these groups in regarding the neurologic impairment at discharge (mRS score at discharge). All but 1 patient with $\mathrm{AE}$ improved clinically. The improvement was for all patients $(\Delta$ mRS score, $p=0.0001)$. However, with regard to the AI status, an improvement was only found in patients without an elevated $\mathrm{AI}(\Delta \mathrm{mRS}$ score, $p=0.0092)$ or with only 1 elevated AI against neurotropic viruses $(\Delta \mathrm{mRS}$ score, $p=0.0310$ ).

\section{Discussion}

Here, we comprehensively assessed the AI against EBV and common neurotropic viruses in $\mathrm{AE}$ compared with $\mathrm{MS}$ and NIND to elucidate whether the immune response is either virus specific or part of a polyclonal immune response. The intrathecally produced antibodies against EBV and other neurotropic viruses (measles, rubella, VZV, HSV, and CMV) in patients with $\mathrm{AE}, \mathrm{MS}$, and NIND were determined.

Our study found an elevated AI against EBV in both patients with $\mathrm{AE}$ and in patients with MS but not in patients with NIND. An $\mathrm{EBV}$ infection of the CNS as a trigger for autoimmune responses eventually causing MS has been largely discussed. ${ }^{6,15,16}$ In a recent study by Abrahamyan et al., ${ }^{17}$ a complete EBV seropositivity in a large cohort of patients with MS could be demonstrated, which strengthens the role of EBV in MS. However, several studies revealed only a low frequency of intrathecally produced antibodies against EBV in different cohorts of patients with MS, which is in line with our findings. ${ }^{6,18-23}$

The role of HSV in the pathogenesis of AE has also been explored. ${ }^{24}$ An infection of the CNS with HSV is clinically characterized by a decrease in consciousness, altered mental state, and seizures. ${ }^{25}$ An elevated AI against HSV can usually be found between 1 and 2 weeks after the onset of symptoms. ${ }^{13,21,26}$ HSV encephalitis is supposed to trigger antibodies against the NMDAR, which might explain relapsing neurologic symptoms weeks after the onset of HSV encephalitis. ${ }^{1,27,28}$ Around $20 \%$ of patients with HSV encephalitis are affected by this complication. ${ }^{1,27,29}$ An elevated $\mathrm{AI}$ against HSV was the most frequently found elevated $\mathrm{AI}$ in patients with $\mathrm{AE}$ in our study but was also detected in a small proportion of patients with MS. On the other hand, an elapsed HSV encephalitis 3 months before diagnosis of antiNMDA R encephalitis was documented in 1 patient, but the AI against HSV was not elevated. This singular finding is in contrast to the assumption that virus-caused antibody synthesis is higher than the synthesis in a polyspecific immune response. ${ }^{26}$ The elevated AI against both viruses EBV and HSV should therefore be considered not only as an immunologic scar to a former infection but also in an autoimmunologic context. The MRZ reaction was reported to be positive in approximately $75 \%$ of all patients with MS. ${ }^{30}$ Here, the MRZ reaction was positive in $19 \%$ of patients with $\mathrm{AE}$ and in $23 \%$ of patients with MS. However, it was lower than in previously reported cohorts, which could be caused by the relatively small cohort size. The similar yet distinct polyclonal immunoreaction indicates a common pathophysiology that might explain the recently described coexistence of MS and anti-NMDAR encephalitis. ${ }^{31}$ This polyclonal immunoreaction was absent in patients with LGI1 AE.

In our study, all patients with $\mathrm{AE}$ or MS with an intrathecal immunoglobulin synthesis against EBV-EBNA-1 or EBVVCA exhibited at least an intrathecal immunoglobulin synthesis against 1 other neurotropic virus. A similar result was found for HSV. In all but 2 patients with AE who had an elevated AI against HSV, AIs against other neurotropic viruses were also elevated.

These findings indicate that the evidence for an immune reaction against neurotropic viruses is rather part of a polyclonal response than a virus targeted humoral immune response after a CNS infection. However, it cannot be ruled out that one of the neurotropic viruses is responsible for triggering the diverse cellular immune mechanisms that cause the autoimmune phenomenon after an infection. ${ }^{21}$ In a short-term follow-up only covering the time in the primary care acute hospital, we could only find slight hints that a lacking intrathecal synthesis against neurotropic viruses could serve as a prognostic marker for a better outcome. A similar finding was described for MS, in which an intrathecal measles virus IgG synthesis correlates with disease activity on MRI. ${ }^{14}$ The MRZ reaction might also serve as a risk factor indicating conversion to $\mathrm{MS}^{32}$ On the other hand, abnormalities in standard CSF parameters do not appear to affect prognosis in patients with $\mathrm{AE}^{33}$

One major limitations of this study is the relatively small size of the cohort, which is due to the rarity of AE. Medical records about childhood infections and earlier vaccinations against neurotropic viruses were not available and would have been interesting to put in consideration with antibody findings. A further limitation is the observational character of the data collected from the multicenter registry.

In conclusion, an intrathecal polyspecific immune response against various neurotropic viruses can be observed in $\mathrm{AE}$ similar to MS suggesting that the MRZ reaction is not specific 
for MS. The pattern of this polyclonal response differs in both diseases and could be a hint to the prevailing autoimmune pathophysiology. Elevated AIs against EBV were always accompanied by other AI against neurotropic virus, indicating that $\mathrm{AE}$ is more than a postinfectious neurologic disorder. We suggest determining AIs against neurotropic viruses and especially EBV during follow-up CSF examinations to further elucidate the role of these viruses in $\mathrm{AE}$.

\section{Acknowledgment}

The authors thank Karin Fricke, Sabine Lang, Katharina Dorsch, and Ilona Cierpka-Leja for excellent technical assistance. The work was supported by members of the GENERATE network, who contributed to patient recruitment, data acquisition, and entry. All members of the GENERATE network as of March 2021 are indicated in Appendix 2.

\section{Study Funding}

This work was supported by the Bundesministerium für Bildung und Forschung (CONNECT-Generate, 01GM1908). This study was partly funded by the Deutsche Forschungsgemeinschaft (DFG, German Research Foundation) under Germany's Excellence Strategy-EXC 2155-Projektnummer 390874280 (to MS).

\section{Disclosure}

M. Ringelstein received speaker honoraria from Novartis, Bayer Vital GmbH, Roche, Alexion, and Ipsen and travel reimbursement from Bayer Schering, Biogen Idec, Merz, Genzyme, Teva, Roche, and Merck. I. Ayzenberg received personal fees from Roche, Alexion, and Merck and received research support from Diamed, none related to this manuscript. The other authors report no disclosures relevant to the manuscript. Go to Neurology.org/NN for full disclosures.

\section{Publication History}

Received by Neurology: Neuroimmunology \& Neuroinflammation March 24, 2021. Accepted in final form June 21, 2021.

Appendix 1 Authors

\begin{tabular}{lll}
\hline Name & Location & Contribution \\
\hline $\begin{array}{l}\text { Philipp } \\
\text { Schwenkenbecher, } \\
\text { MD }\end{array}$ & $\begin{array}{l}\text { Department of } \\
\text { Neurology, Hannover } \\
\text { Medical School, } \\
\text { Hannover, Germany }\end{array}$ & $\begin{array}{l}\text { Designed and } \\
\text { conceptualized the } \\
\text { study; analyzed the data; } \\
\text { and drafted the } \\
\text { manuscript }\end{array}$ \\
\hline $\begin{array}{l}\text { Thomas Skripuletz, } \\
\text { MD }\end{array}$ & $\begin{array}{ll}\text { Department of } \\
\text { Neurology, Hannover } \\
\text { Medical School, } \\
\text { Hannover, Germany }\end{array}$ & $\begin{array}{l}\text { Interpreted the data and } \\
\text { revised the manuscript } \\
\text { for intellectual content }\end{array}$ \\
\hline Peter Lange & $\begin{array}{l}\text { Department of } \\
\text { Neurology, Georg August } \\
\text { University Götingen, } \\
\text { Göttingen, Germany }\end{array}$ & $\begin{array}{l}\text { Acquisition of data; } \\
\text { analyzed the data; and } \\
\text { revised the manuscript } \\
\text { for intellectual content }\end{array}$ \\
\hline
\end{tabular}

Appendix 1 (continued)

\begin{tabular}{|c|c|c|}
\hline Name & Location & Contribution \\
\hline Marc Dürr, MD & $\begin{array}{l}\text { Department of } \\
\text { Neurology, Ulm } \\
\text { University, Ulm, } \\
\text { Germany }\end{array}$ & $\begin{array}{l}\text { Acquisition of data; } \\
\text { analyzed the data; } \\
\text { and revised the } \\
\text { manuscript for } \\
\text { intellectual } \\
\text { content }\end{array}$ \\
\hline Franz Konen, MD & $\begin{array}{l}\text { Department of } \\
\text { Neurology, Hannover } \\
\text { Medical School, } \\
\text { Hannover, Germany }\end{array}$ & Acquisition of data \\
\hline Nora Möhn, MD & $\begin{array}{l}\text { Department of } \\
\text { Neurology, Hannover } \\
\text { Medical School, } \\
\text { Hannover, Germany }\end{array}$ & $\begin{array}{l}\text { Interpreted the data and } \\
\text { revised the manuscript } \\
\text { for intellectual content }\end{array}$ \\
\hline $\begin{array}{l}\text { Marius Ringelstein, } \\
\text { MD }\end{array}$ & $\begin{array}{l}\text { Department of } \\
\text { Neurology, Medical } \\
\text { Faculty, Heinrich-Heine- } \\
\text { University Düsseldorf, } \\
\text { Düsseldorf, Germany; } \\
\text { Department of } \\
\text { Neurology, Centre for } \\
\text { Neurology and } \\
\text { Neuropsychiatry, LVR- } \\
\text { Klinikum, Heinrich- } \\
\text { Heine-University } \\
\text { Düsseldorf, Düsseldorf, } \\
\text { Germany }\end{array}$ & $\begin{array}{l}\text { Interpreted the data and } \\
\text { revised the manuscript } \\
\text { for intellectual content }\end{array}$ \\
\hline Til Menge, MD & $\begin{array}{l}\text { Department of } \\
\text { Neurology, Centre for } \\
\text { Neurology and } \\
\text { Neuropsychiatry, LVR- } \\
\text { Klinikum, Heinrich- } \\
\text { Heine-University } \\
\text { Düsseldorf, Düsseldorf, } \\
\text { Germany }\end{array}$ & $\begin{array}{l}\text { Interpreted the data and } \\
\text { revised the manuscript } \\
\text { for intellectual content }\end{array}$ \\
\hline $\begin{array}{l}\text { Manuel A. Friese, } \\
\text { MD }\end{array}$ & $\begin{array}{l}\text { Institute of } \\
\text { Neuroimmunology and } \\
\text { Multiple Sclerosis, } \\
\text { University Medical } \\
\text { Center Hamburg- } \\
\text { Eppendorf, Hamburg, } \\
\text { Germany }\end{array}$ & $\begin{array}{l}\text { Interpreted the data and } \\
\text { revised the manuscript } \\
\text { for intellectual content }\end{array}$ \\
\hline Nico Melzer, MD & $\begin{array}{l}\text { Department of } \\
\text { Neurology with Institute } \\
\text { of Translational } \\
\text { Neurology, University } \\
\text { Hospital Muenster, } \\
\text { Muenster, Germany }\end{array}$ & $\begin{array}{l}\text { Interpreted the data and } \\
\text { revised the manuscript } \\
\text { for intellectual content }\end{array}$ \\
\hline $\begin{array}{l}\text { Michael P. Malter, } \\
\text { MD }\end{array}$ & $\begin{array}{l}\text { Department of } \\
\text { Neurology, University } \\
\text { Hospital Cologne, } \\
\text { Cologne, Germany }\end{array}$ & $\begin{array}{l}\text { Interpreted the data and } \\
\text { revised the manuscript } \\
\text { for intellectual content }\end{array}$ \\
\hline Martin Häusler, MD & $\begin{array}{l}\text { Division of } \\
\text { Neuropediatrics and } \\
\text { Social Pediatrics, } \\
\text { Department of } \\
\text { Pediatrics, Medical } \\
\text { Faculty, RWTH Aachen } \\
\text { University, Aachen, } \\
\text { Germany }\end{array}$ & $\begin{array}{l}\text { Interpreted the data and } \\
\text { revised the manuscript } \\
\text { for intellectual content }\end{array}$ \\
\hline $\begin{array}{l}\text { Franziska S. Thaler, } \\
\text { MD }\end{array}$ & $\begin{array}{l}\text { Institute of Clinical } \\
\text { Neuroimmunology, } \\
\text { University Hospital and } \\
\text { Biomedical Center, } \\
\text { Ludwig-Maximilians } \\
\text { University Munich, } \\
\text { Munich, Germany }\end{array}$ & $\begin{array}{l}\text { Interpreted the data and } \\
\text { revised the manuscript } \\
\text { for intellectual content }\end{array}$ \\
\hline
\end{tabular}


Appendix 1 (continued)

\begin{tabular}{lll}
\hline Name & Location & Contribution \\
\hline Martin Stangel, MD & $\begin{array}{l}\text { Department of } \\
\text { Neurology, Hannover } \\
\text { Medical School, } \\
\text { Hannover, Germany }\end{array}$ & $\begin{array}{l}\text { Interpreted the data and } \\
\text { revised the manuscript } \\
\text { for intellectual content }\end{array}$ \\
\hline Jan Lewerenz, MD & $\begin{array}{l}\text { Department of } \\
\text { Neurology, Ulm } \\
\text { University, Ulm, } \\
\text { Germany }\end{array}$ & $\begin{array}{l}\text { Interpreted the data and } \\
\text { revised the manuscript } \\
\text { for intellectual content }\end{array}$ \\
\hline $\begin{array}{l}\text { Kurt-Wolfram Sühs, } \\
\text { MD }\end{array}$ & $\begin{array}{l}\text { Department of } \\
\text { Neurology, Hannover } \\
\text { Medical School, } \\
\text { Hannover, Germany }\end{array}$ & $\begin{array}{l}\text { Designed and } \\
\text { conceptualized the } \\
\text { study; analyzed the data; } \\
\text { and drafted the } \\
\text { manuscript }\end{array}$ \\
\hline
\end{tabular}

\section{Appendix 2 Coinvestigators}

German Network for Research on Autoimmune Encephalitis (GENERATE) coinvestigators are listed in Appendix 2 at links.Iww.com/NXI/A541.

\section{References}

1. Dalmau J, Graus F. Antibody-mediated encephalitis. N Engl J Med. 2018;378(9): 840-851.

2. Dalmau J, Geis C, Graus F. Autoantibodies to synaptic receptors and neuronal cell surface proteins in autoimmune diseases of the central nervous system. Physiol Rev. 2017;97(2):839-887.

3. Nosadini M, Mohammad SS, Corazza F, et al. Herpes simplex virus-induced anti-Nmethyl-d-aspartate receptor encephalitis: a systematic literature review with analysis of 43 cases. Dev Med Child Neurol. 2017;59(8):796-805.

4. Prakash PA, Jin J, Matharu K, et al. Anti-NMDAR encephalitis with concomitant varicella zoster virus detection and nonteratomatous malignancy. Neurol Neuroimmunol Neuroinflamm. 2019;6(2):e537.

5. Garré J, Sprengers M, Van Melkebeke D, Laureys G. EBV-NMDA double positive encephalitis in an immunocompromised patient. J Neurol Sci. 2019;396:76-77.

6. Ruprecht K, Wildemann B, Jarius S. Low intrathecal antibody production despite high seroprevalence of Epstein-Barr virus in multiple sclerosis: a review of the literature. J Neurol. 2018;265(2):239-252

7. Ascherio A, Munger KL. Environmental risk factors for multiple sclerosis. Part I: the role of infection. Ann Neurol 2007;61(4):288-299.

8. Ascherio A, Munger KL, Lennette ET, et al. Epstein-Barr virus antibodies and risk of multiple sclerosis: a prospective study. JAMA. 2001;286(24):3083-3088.

9. Pakpoor J, Disanto G, Gerber JE, et al. The risk of developing multiple sclerosis in individuals seronegative for Epstein-Barr virus: a meta-analysis. Mult Scler. 2013; 19(2):162-166.

10. Graus F, Titulaer MJ, Balu R, et al. A clinical approach to diagnosis of autoimmune encephalitis. Lancet Neurol. 2016;15(4):391-404.

11. Reiber H. Cerebrospinal fluid: physiology, analysis and interpretation of protein patterns for diagnosis of neurological diseases. Mult Scler. 1998;4(3):99-107.
12. Reiber $\mathrm{H}$, Lange P. Quantification of virus-specific antibodies in cerebrospinal fluid and serum: sensitive and specific detection of antibody synthesis in brain. Clin Chem. 1991;37(7):1153-1160.

13. Reiber H, Peter JB. Cerebrospinal fluid analysis: disease-related data patterns and evaluation programs. J Neurol Sci. 2001;184(2):101-122.

14. Rosche B, Laurent S, Conradi S, Hofmann J, Ruprecht K, Harms L. Measles IgG antibody index correlates with T2 lesion load on MRI in patients with early multiple sclerosis. PLoS One. 2012;7(1):e28094.

15. Otto C, Hofmann J, Ruprecht K. Antibody producing B lineage cells invade the central nervous system predominantly at the time of and triggered by acute Epstein Barr virus infection: a hypothesis on the origin of intrathecal immunoglobulin synthesis in multiple sclerosis. Med Hypotheses. 2016;91:109-113.

16. Pfuhl C, Oechtering J, Rasche L, et al. Association of serum Epstein-Barr nuclear antigen-1 antibodies and intrathecal immunoglobulin synthesis in early multiple sclerosis. J Neuroimmunol. 2015;285:156-160.

17. Abrahamyan S, Eberspächer B, Hoshi MM, et al. Complete Epstein-Barr virus seropositivity in a large cohort of patients with early multiple sclerosis. J Neurol Neurosurg Psychiatry. 2020;91(7):681-686.

18. Castellazzi M, Contini C, Tamborino C, et al. Epstein-Barr virus-specific intrathecal oligoclonal IgG production in relapsing-remitting multiple sclerosis is limited to a subset of patients and is composed of low-affinity antibodies. J Neuroinflammation. 2014;11:188.

19. Castellazzi M, Tamborino C, Cani A, et al. Epstein-Barr virus-specific antibody response in cerebrospinal fluid and serum of patients with multiple sclerosis. Mult Scler. 2010;16(7):883-887.

20. Otto C, Oltmann A, Stein A, et al. Intrathecal EBV antibodies are part of the polyspecific immune response in multiple sclerosis. Neurology. 2011;76(15):1316-1321.

21. Pohl D, Rostasy K, Jacobi C, et al. Intrathecal antibody production against Epstein Barr and other neurotropic viruses in pediatric and adult onset multiple sclerosis. J Neurol. 2010;257(2):212-216.

22. Rand KH, Houck H, Denslow ND, Heilman KM. Epstein-Barr virus nuclear antigen-1 (EBNA-1) associated oligoclonal bands in patients with multiple sclerosis. J Neurol Sci. 2000;173(1):32-39.

23. Villegas E, Santiago O, Carrillo JA, et al. Low intrathecal immune response of antiEBNA-1 antibodies and EBV DNA from multiple sclerosis patients. Diagn Microbiol Infect Dis. 2011;70(1):85-90.

24. Dalmau J, Armangué $\mathrm{T}$, Planagumà $\mathrm{J}$, et al. An update on anti-NMDA receptor encephalitis for neurologists and psychiatrists: mechanisms and models. Lancet Neurol. 2019;18(11):1045-1057.

25. Whitley RJ. Herpes simplex encephalitis: adolescents and adults. Antivir Res. 2006; 71(2-3):141-148.

26. Jacobi C, Lange P, Reiber H. Quantitation of intrathecal antibodies in cerebrospinal fluid of subacute sclerosing panencephalitis, herpes simplex encephalitis and multiple sclerosis: discrimination between microorganism-driven and polyspecific immune response. J Neuroimmunol. 2007;187(1-2):139-146.

27. Armangue T, Leypoldt F, Dalmau J. Autoimmune encephalitis as differential diagnosis of infectious encephalitis. Curr Opin Neurol. 2014;27(3):361-368.

28. Linnoila JJ, Binnicker MJ, Majed M, Klein CJ, McKeon A. CSF herpes virus and autoantibody profiles in the evaluation of encephalitis. Neurol Neuroimmunol Neuroinflamm. 2016;3(4):e245.

29. Hacohen $Y$, Deiva K, Pettingill P, et al. N-methyl-D-aspartate receptor antibodies in postherpes simplex virus encephalitis neurological relapse. Mov Disord. 2014;29(1):90-96

30. Jarius S, Eichhorn P, Franciotta D, et al. The MRZ reaction as a highly specific marker of multiple sclerosis: re-evaluation and structured review of the literature. J Neurol. 2017;264(3):453-466.

31. Gulec B, Kurucu H, Bozbay S, et al. Co-existence of multiple sclerosis and anti-NMDA receptor encephalitis: a case report and review of literature. Mult Scler Relat Disord. 2020;42:102075.

32. Brettschneider J, Tumani H, Kiechle U, et al. IgG antibodies against measles, rubella, and varicella zoster virus predict conversion to multiple sclerosis in clinically isolated syndrome. PLoS One. 2009;4(11):e7638.

33. Broadley J, Seneviratne U, Beech P, et al. Prognosis in autoimmune encephalitis database. Data Brief. 2018;21:2694-2703. 


\title{
Neurology \\ Neuroimmunology \& Neuroinflammation
}

\author{
Intrathecal Antibody Production Against Epstein-Barr, Herpes Simplex, and Other \\ Neurotropic Viruses in Autoimmune Encephalitis \\ Philipp Schwenkenbecher, Thomas Skripuletz, Peter Lange, et al. \\ Neurol Neuroimmunol Neuroinflamm 2021;8; \\ DOI 10.1212/NXI.0000000000001062
}

This information is current as of August 24, 2021

Updated Information \&

Services

References

Citations

Permissions \& Licensing

Reprints including high resolution figures, can be found at:

http://nn.neurology.org/content/8/6/e1062.full.html

This article cites 33 articles, 4 of which you can access for free at: http://nn.neurology.org/content/8/6/e1062.full.html\#\#ref-list-1

This article has been cited by 1 HighWire-hosted articles:

http://nn.neurology.org/content/8/6/e1062.full.html\#\#otherarticles

Information about reproducing this article in parts (figures,tables) or in its entirety can be found online at:

http://nn.neurology.org/misc/about.xhtml\#permissions

Information about ordering reprints can be found online: http://nn.neurology.org/misc/addir.xhtml\#reprintsus

Neurol Neuroimmunol Neuroinflamm is an official journal of the American Academy of Neurology.

Published since April 2014, it is an open-access, online-only, continuous publication journal. Copyright

Copyright (C) 2021 The Author(s). Published by Wolters Kluwer Health, Inc. on behalf of the American

Academy of Neurology.. All rights reserved. Online ISSN: 2332-7812.



